Article

\title{
"This World Is Not My Home": Richard Mouw and Christian Nationalism
}

\author{
Aaron Pattillo-Lunt \\ Spring Arbor University, Spring Arbor, MI 49283, USA; aaron.lunt@arbor.edu \\ Academic Editors: Mark T. Edwards and Christine A. James \\ Received: 6 November 2016; Accepted: 23 December 2016; Published: 27 December 2016
}

\begin{abstract}
American evangelicalism has often been punctuated by dual commitments to the United States and to God. Those commitments were strongest within politically conservative evangelicalism. Though representing a solid majority among professing evangelicals, conservatives could not speak for the movement as a whole. Politically progressive evangelicals, beginning in the 1960s, formed a dissenting opinion of the post-World War II revival of Christian nationalism. They dared to challenge American action abroad, noticeably during the Vietnam War. Their critique of Christian nationalism and conservative evangelicals' close ties to the Republican Party led them to seek refuge in either progressive policies or the Democratic Party. A third, underexplored subgroup of evangelicalism rooted in reformed theology becomes important to consider in this regard. These reformed evangelicals sought to contextualize nationalism in biblical rather than partisan or political terms. This goal is championed well by Richard Mouw, resulting in a nuanced look at evangelical Christians' difficult dual role as both citizens of the Kingdom of God and the United States.
\end{abstract}

Keywords: evangelicalism; nationalism; Mouw; reformed; Calvinism; Kuyper; Biblicism

\section{Introduction}

Evangelicalism is one of the most pervasive and dominant movements in United States' history. Yet it has no cut and paste definition. It is diverse and adaptive. Despite this changeability, evangelicals can be loosely defined by their theological views. They are religiously orthodox regardless of their political views. This belief is compounded by a staunch Biblicism, meaning evangelicals take the Bible as the highest authority over all of life. The difficulty of this approach lies in the protestant understanding of the priesthood of believers which affords endless interpretations of the sacred text ([1], p. 7). This informs the diversity within the movement. Different subgroups read the Bible differently and appropriate it as necessary. The consequence of this belief is a fractured movement, united by a firm belief that the Bible is supreme.

A close examination of American evangelicalism reveals that evangelicals do not have a unified approach to American history either. This essay seeks to explore just three such approaches. An acceptance of a Christian America is the dominant view in the movement and is perpetuated by politically conservative evangelicals, henceforth labeled conservative evangelicals. Politically progressive evangelicals, henceforth called progressive evangelicals, critique this view. They argue America cannot be considered uniquely Christian or chosen by God. The last view cannot be politically labeled. Its adherents reach across the aisle and are driven by reformed theology when approaching nationalism. These reformed evangelicals approach American Christianity with an integrationist viewpoint. They are more comfortable recognizing America as a chosen nation, though their understanding of chosen-ness differs from that of conservative evangelicalism. Reformed evangelicals are also critical of the United States' actions nationally and internationally. By injecting a third evangelical subgroup into a discussion on Christian nationalism, this paper intends to reinforce the reality of a diverse evangelicalism through the exploration of a thinker representative 
of reformed evangelicalism. Before considering these differing viewpoints, a brief understanding of how America can be considered a Christian nation must be discussed. Considering the important role that conservative evangelicals play in advancing this view of the past, they must be inserted into the narrative.

Conservative evangelicals' identity as citizens is rooted in their view of the past. Prominently, they identify their nation as firmly Christian, formed with biblical principles in mind. By doing so, conservative evangelicals find their identity as citizens in their nation's supposedly religious origins. This results in an understanding of history which promotes a distinctly Christian brand of nationalism and a belief that America is exceptional because it is chosen by God.

Proof-texting allows Christian nationalists to utilize documents from the colonial and founding period to support their claims. John Winthrop's "Citty [sic] upon a hill" statement is one key example ([2], p. 65). To the Christian nationalist, Winthrop employed these words to indicate that Puritan settlements in North America were intended by God to be a shining and exportable example to the rest of the world. This allows one to read a sense of divine calling into Winthrop's mission. As historians have pointed out, this reading of history is incomplete. Winthrop's words were meant to be internalized not externalized. Puritans were not to have an exceptional view of themselves. Rather, they were expected by Winthrop to behave themselves so their mission would not fail under the watchful "eies of all people [Puritans still in England] ([2], p. 65)". Winthrop worried moral failure would discredit the Puritans' mission. His words are, therefore, best seen as directed to a specific community for a specific purpose. He sought to build a local, religious, and guilt free community, not construct a national, Christian example.

Regardless of this historical corrective, conservative evangelicals tend to favor a providential viewing of history. A number of prominent evangelicals rise to the fore in this regard-Tim LaHaye (1926-2016), Peter Marshall (b. 1964), and, most recently, David Barton (b. 1954). These three men, and others like them, worked to ensure the myth of a Christian America, as historian Stephen Green titled it, is spread [2]. Marshall and Barton are popular evangelical authors specializing in writing revisionist histories which seek to irrevocably connect Christianity and the United States. Their success is evident when one looks at conservative evangelical circles. These evangelicals are more likely to see the United States' formative years, such as Peter Marshall who commonly asked rhetorically affirmative questions-“Wasn't Christopher Columbus inspired by the Holy Spirit as he sailed west? Weren't the pilgrims who landed on New England's rocky shores driven by divine purpose?"- to enforce this viewing of history ([3], p. 75). These perceptions are incredibly persistent, lasting into the twenty-first century. Conservative evangelical figures continue to comment on the seemingly providential rise to power of the United States, particularly as it pertains to the nation's special, or exceptional, role in God's plan.

This leaves conservative evangelicalism touting a triumphalist, providentially driven view of Christian nationalism. It is a perception that is advanced in this evangelical subgroup's approach to both politics and history. To be clear, a belief in Christian nationhood does not mean that conservative evangelicals trust or even support the government. Instead, they seek to return their nation to its Christian moorings, opposing secularism and progressivism as antithetical to Christianity. This goal led to an alliance with the Republican Party that became solidified in the 1980s.

Despite the power of this conservative line of thought, opposition to the myth of a Christian America can be found in works put forth by evangelical scholars, such as Mark Noll and John Fea, and progressive figures within the movement, such as Jim Wallis or Ronald Sider. This paper will first discuss how leading figures within conservative and progressive evangelicalism have tackled the issue of Christian nationalism. Then its focus will shift towards reformed evangelicalism and the works of Richard Mouw as an example of an evangelical who sidesteps progressive and conservative evangelical approaches to nationalism with an insider's perspective of the movement.

Mouw is a professor of philosophy who taught at both Wheaton and Fuller Theological Seminary-two of the most prominent evangelical schools in the United States. He also served as the 
president of Fuller from 1993 to 2013. He offers a corrective of Christian nationalism based within evangelicals' own conception of the authoritative role of the Bible and God. Of special importance is how Mouw challenges both progressive and conservative evangelicals to return to their Biblicist roots by using the Bible for its own purposes rather than appropriating it for political or national means. Through his argument, a nonpartisan, third way for evangelicals to approach the issue of nationalism becomes apparent.

\section{Results}

\subsection{Belief: Christian Nationalism in the Conservative Evangelical Movement}

Twentieth century evangelicalism descended from the late nineteenth and early twentieth centuries' fundamentalist movement. Fundamentalists were theologically orthodox, separated themselves from the dominant culture, and believed strongly in premillennial dispensationalism. Their beliefs did not include, at least inherently, a strongly nationalistic tendency. Rather, they built small citadels of the faith in every church body that could be viewed as holy amidst a culture and a nation too corrupt to save. From these fortresses, they could preach the end was nigh, hoping to save a final few before Armageddon. Indeed, social engagement was deemed foolish in such a climate ([4], p. 15). Therefore, while neo-evangelicals (referred to only as evangelicals in this paper as the evangelicals of the 19th century are not discussed) were theological descendants of the fundamentalists, their social engagement and their patriotism signified a distinct break from their parent movement. A look at conservative evangelicalism's rise to social prominence indicates how leaders within the movement reconciled fundamentalism's strict theological orthodoxy and deep concern for the prophetic with a strict nationalism.

This reconciliation began with the mid and post-World War II resurgence of evangelicalism. Carl Henry's 1947 jeremiad, The Uneasy Conscience of Modern Fundamentalism, signaled an increase in social engagement among evangelicalism as a whole ([5], p. 52). This book was, in many ways, a response to an opportunity which arose in World War II. By 1941, a number of marginalized groups in America found acceptance in the larger culture by supporting the United States' military conflicts ([6], pp. 217-18). ${ }^{1}$ Evangelicals did likewise. In asserting their support for the war and its religious aims-defending religious liberty and thereby democracy — they overcame fundamentalism's extremist and detached reputation ([6], pp. 370-71). By doing so, evangelicals indicated that they could not be the same separatist group that radically stood against modernization and religious and political progressivism while still holding on to key tenets of fundamentalism. Simply put, the war allowed conservative evangelicals to market themselves as a deeply patriotic group committed to the political and social success of their nation.

For the post-war, conservative evangelical, this national outlook rooted itself in a deeply held belief that America was chosen by God, had a prophetic destiny, and was designed to be Christian. This myth did not originate after World War II. It extended back to revisionist histories written dating back to the 1790s and through the 1800s ([2], pp. 199-41). Regardless, conservative evangelicals had good reasons to contend that America was a Christian nation in the post-war years. An increase in civil religion made it easier for conservative evangelicals to build on the Christian America myth by looking at the past. Historian Kevin Kruse illustrated how a Christian America was reinforced beginning in the 1930s as a response to the New Deal rather than during the nation's formative years in the eighteenth century [7].

In an effort to regain their post-depression reputations, businesses around the country found an unlikely ally in American pastors ([7], p. 4). James W. Fifield Jr. served as the chief pastoral lobbyist for

1 Preston's work details how a number of groups-Irish Americans, Catholics, and Mormons-all joined the military and supported actions abroad, such as the Spanish American War and the colonization of the Philippines to indicate their loyalty to the United States and overcome marginalization. 
businesses and conservatism. (Fifield was not an evangelical, but his work did provide a foundation that conservative evangelicals utilized to advance their nationalistic beliefs.) He opposed the New Deal for its collectivistic tendencies, something he contended to be unbiblical and un-American, and he praised businesses and conservative values for their libertarian conceptions, something he contended to be deeply biblical ([7], pp. 6-7). Furthermore, Fifield was able to contrast conservatism and his vision for a Christian America with the collectivistic tendencies of America's enemies, such as Nazi Germany and, in time, Soviet Russia. He formed Spiritual Mobilization to champion his perception of the Bible and America, one rooted in individual liberty as opposed to "pagan statetism" ([7], p. 14). Spiritual Mobilization rallied pastors around the nation to this cause, forming the foundation of a nation that was perceived to be under God years before those words formed part of the United States' unofficial motto under President Eisenhower. Conservative evangelicals built upon this framework in the post-war years to defend the assertion that God stood with and for the United States ([8], pp. $76-96){ }^{2}$ Despite these realities, there were few indications that conservative evangelicals would embrace Christian nationalism as fully as they have.

The evangelical elite began to organize even before Henry's jeremiad. Harold Ockenga (1905-1985) was important in this regard. He was very educated, an attendee of Princeton Theological Seminary, and he helped form the National Association of Evangelicals (NAE) in 1943 ([9], pp. 147-50). Additionally, Ockenga had strong conservative impulses. Therefore, his thoughts on America's role in the world require consideration due to their thoughtful nature.

Ockenga's deeply evangelical approach to America's divine role rooted itself in the belief that evangelicals, particularly American evangelicals, would play a vital role in halting the "disintegration of Christianity" and the "break-up of the moral fiber of the American people" ([9], p. 147). This was his prime impetus for beginning the NAE and accepting the presidential role in the organization. In one of his first addresses to the NAE, titled "Christ in America," Ockenga laid out his vision. He believed "the United States of America has been assigned a destiny comparable to that of ancient Israel" ([9], p. 149). Evangelicals were destined to lead the "rescue of western civilization ... by a revival of evangelical Christianity" ([9], p. 149). Ockenga's address made sense in the post-war context. Indeed, as Joel Carpenter points out, "Ockenga was hopeful the trial of war would promote a fresh tide of 'common sense, faith [and] vision'” ([9], p. 149). To Ockenga then, America's post-war destiny was to lead a moral revolution against the idols of "blood, power, sex, money, hunger, strong men, and strong weapons" ([9], p. 149). Indeed, he felt America in general, and evangelicals in particular, were called by God to bring about this revival of western Christianity. Despite his many attempts to lead this revival, Ockenga was unable to capture the audience required to make his dream a reality. Somewhat reluctantly, he passed his vision on to a rising star in the movement ([9], p. 226). It is here that Billy Graham's role as a leader of the movement becomes important to consider.

After a 1949 rally, Graham became the rising star and the public face of the evangelical movement. His staunch opposition to communism, his belief in free enterprise, and his many connections to big business made him a powerful defender of American conservatism as well ([7], p. 37). By strengthening evangelicalism's affiliations with the presidency-Graham was a notable asset to the Eisenhower, Johnson, and Nixon administrations-he connected the religious movement to the White House like never before. Despite an extremely close relationship with Johnson and attempts to remain non-partisan, Graham's social conservatism connected him more closely with Republican policies. This was a mutually beneficial relationship. The party gained a massive constituency, and evangelicals gained a powerful ally, one they could partner with to champion America's exceptional nature.

One such example of this can be found in Graham's Honor America Day. This religious and political event, which doubled as a rally for Nixon, was held in Washington D.C. on July 4, 1970. The

2 Giberson and Stephens chronicle how Peter Marshall and David Manuel's The Light and the Glory and David Barton's organization Wallbuilders have disseminated this providential view of history. They argue evangelicals tend to care little that works by these men have often been debunked by professional historians. 
event's organizers intended to restore Americans' faith in their nation, despite its controversial actions abroad. Graham, in an attempt to invoke the memory of Martin Luther King Jr., titled his sermon "The Unfinished Dream" ([7], p. 268). He reminded his audience "The Bible says, 'Honor the nation.' As a Christian, or as a Jew, or as an atheist" ([7], p. 268). Graham was preaching to the choir. He urged his listeners to remember "The men who signed the Declaration of Independence were moved by a magnificent dream. This dream was rooted in a book called the Bible" ([7], p. 268). In essence, Graham spoke both to condemn the left-wing radicalism of the 1960s and to emphasize the United States' Christian origins. The conservative evangelical turnout to Honor America Day is difficult to gauge, but Graham's influence in the movement cannot be understated. Furthermore, the entire event was filmed and sold as a two-disc album narrated by Jimmy Stewart and titled Proudly They Came ... To Honor America ([7], p. 278). It quickly sold out. As Graham aged and suffered through political errors, he stepped away from a staunch nationalism. When the Watergate scandal broke, Graham stepped away from politics, in no small part because Graham nearly endorsed Nixon in 1960 as the moral candidate ([10], p. 209). ${ }^{3}$ Post-Watergate, Graham recognized his continual support for Nixon, and other politicians, had the potential to diminish his evangelistic efforts. This disengagement from politics allowed others to take his place ([10], p. 293).

Jerry Falwell stands as a prominent replacement to Graham. He rallied a significant number of evangelicals in the contemporary era through Moral Majority-a political action group he formed in 1979 ([11], p. 340). The group gained ecumenical support behind a pro-life and traditional family values platform. Throughout the 1980s, it primarily worked to shift elections in favor of conservative values and to champion a belief that America needed to be returned to its Christian roots. When it came to Christian nationalism, Falwell was a disciple of Francis Schaeffer (1912-1984). Schaeffer's belief in a Christian America was fleshed out in a yearlong debate with George Marsden and Mark Noll—evangelicals and professionally trained historians. Schaeffer set out to prove the founders' general ideas were biblical, even if their writings did not explicitly mention the Bible. He called for evangelicals to return to the methods the founders employed politically ([12], p. 212). Noll retorted by indicating the ambivalence and even distaste that some of the founders had for the Bible, particularly Jefferson and Madison. Noll's rebuke infuriated Schaeffer. He labeled Noll's approach to history as something common among "weak Christians" ([12], p. 215). Falwell, mimicked Schaeffer's view of the past. He put it succinctly when he said, "We [the religious right] believe our nation must come back to God or else" ([11], p. 554). While this statement can, and should, be understood as a call for religious revival, it cannot be divorced from evangelicals' commitment to emphasize the Christian nature of the United States. The very notion of "coming back to" implies a desire to return to something that tangibly existed. Falwell was, knowingly or unknowingly, making a historical statement cemented in the perception that the United States was losing its Christian grounding. (Schaeffer advanced this argument too.) A call for revival, therefore, can be seen as serving both a religious and historical purpose.

The intent of men such as Graham, Schaeffer, and Falwell to emphasize how Christianity was inherent to the United States' national course has been championed time and again by conservative evangelicalism's most notable figures and self-titled experts. For example, Tim LaHaye claimed "The history of America's ... guiding political philosophy cannot be described without reference to its biblical roots" ([2], p. 5). The strongest contemporary, conservative evangelical champion of these views is David Barton. Barton goes so far as to rewrite history, ignoring facts and proper historical interpretation, in order to perpetuate the myth ([8], pp. 83-96). This leads him to conclude "virtually every one of the fifty-five founding fathers who framed the Constitution were members of orthodox Christian churches and that many were outspoken evangelicals" ([2], p. 137). Despite the numerous

3 Graham went so far as to write an article for Time magazine in 1960 endorsing Nixon because of his "strength, knowledge, wisdom, and integrity as well as faith in God." Henry Luce pulled the article to protect Graham from partisanship. 
historical errors in Barton's assertion, his opinion is respected among members of the evangelical movement. He has even gained a national audience, serving as an expert witness in Supreme Court cases, advising lawmakers, and having a regular slot on Glenn Beck's programs ([8], pp. 84, 87). Additionally, Barton and Peter Marshall were both instrumental advisers for the Texas State Board of Education's 2010 shift towards a conservative history curriculum. To name just one change in the curriculum, Thomas Jefferson was removed from the list of enlightenment thinkers ([8], p. 89). This fits into Barton's agenda to whitewash the founding era in such a way that it lacks any secular impetus. His views are generally accepted because they satisfy conservative evangelicals' presupposition that the United States has a Christian past and a God given destiny.

\subsection{Critique: Progressive Evangelicals and Christian Nationalism}

As David Swartz and Brantley Gasaway have chronicled, progressive evangelicals, along with their conservative brethren, emerged in the post-World War II climate [13,14]. Progressive evangelicalism grew slowly as a subgroup, emerging fully during the protest movements of the 1960s. In this rebellious decade, the subgroup mimicked the left-wing culture that conservative Americans detested. Its members adopted countercultural tactics, dressed like the new left and hippie movements, and modified the rhetoric of these secular youth movements for their Christian purpose. They even began their own publications-The Other Side (first known as Freedom Now) and the Post American (founded by Jim Wallis and eventually retitled Sojourners) — to disseminate their views. These publications championed progressive, Christian approaches to social justice and united the youthful subgroup ([14], p. 25). Progressive evangelicals also joined in anti-Vietnam protests and attacked unquestioning patriotism, pointing out the seeming hypocrisy conservative Christians evidenced by supporting war. They believed the United States' engaged in wars fought without regard for human life. This was a jab at the pro-life reputation of conservative evangelicals. As Charles Fager pointed out, no one could "weep for aborted fetuses" when they wanted to engage in unjust wars abroad ([14], p. 135). Progressive evangelicals could not idly sit by and watch the United States perpetrate violence without regard for the image of God in its foreign victims.

Both Gasaway and Swartz illustrate how progressive evangelicals sought to establish a political platform rooted in social justice. These left-leaning evangelicals intended to create a nonpartisan and biblically based approach to politics. The tangible example of this goal was the "Chicago Declaration of Evangelical Social Concern." This document, written in 1973, was signed by a number of prominent evangelicals from across the political spectrum, including Carl Henry, Jim Wallis, and Richard Mouw ([13], p. 181). The declaration affirmed evangelicals' commitment "to the Lord Jesus Christ and full authority of the Word of God" while denouncing the involvement of the "church in America with racism" and the United States' "pathology of war" ([13], pp. 267-68). The document explicitly stated that its signers endorsed "no political ideology or party" ([13], p. 268).

Of special importance to this paper is the ways progressive evangelicals have protested, and continue to protest, injustices committed by the nation they call home. While not always explicitly stated, hidden behind this willingness is a belief that the United States does not receive special favor by God. Even if the United States were given special favor by God, the nation and its governing bodies still needed to be corrected when national sins went unchallenged or were even supported by public policy. Progressive evangelicals' support for the Civil Rights Movement informs this point. Leading figures in the movement, such as Ronald Sider, spent time living among the marginalized in order to better understand their plight ([13], p. 155). Jim Wallis was influenced by the effects of racism and felt a desire to help the oppressed because of the brutality he witnessed in Detroit's 1967 race riots. Wallis credits the riots as his "baptism of fire," explaining the racism that they evidenced "betrayed the ideals I had been taught as a child" ([13], p. 50). As a result of these views, Wallis and Sider would find themselves outcasts from mainstream, conservative evangelicalism while becoming the rising stars of the progressive evangelical movement. While all evangelicals appealed to the same God and shared many religious beliefs, progressive and conservative evangelicals differed in their interpretation of the 
United States' past and present role in the world. These differences were highlighted by Wallis's 2005 bestseller, God's Politics. God's Politics is a thorough critique of the United States' political atmosphere. It is equal parts admonition and instruction. In writing it, Wallis intended to reach across the aisle by forging a third way in American politics that is not partisan but godly [15]. Wallis also sought to combat the unbreakable alliance between conservative evangelicals and the Republican Party by connecting certain policy measures to biblical precepts.

Wallis spoke out heavily against conservative evangelicals' unquestioning support for George W. Bush and the Iraq War ([16], p. 196). ${ }^{4}$ He did so by questioning the notion that God is on America's side, particularly as God would not stand by a war fought so unjustly. In one of his most poignant assaults on Christian nationalism, Wallis questioned whether "we [Christians] really believe that America and George W. Bush have been divinely appointed to root out evil in the world? That's bad theology and a very dangerous one" ([15], p. 119). He urged conservative evangelicals and politicians to reconsider their support for the war. Another notable critique of Christian nationalism can be found in Wallis's views on racism, especially his label for it, "America's original sin" ([15], pp. 307-8). By titling racism thus, Wallis is making an implicit argument that the United States and the will of God cannot be seen as linked due to the nation's sinful tendencies.

While Wallis builds an interesting political argument against the prominence of Christian nationalism in the evangelical movement, his argument lacks a distinctly biblical and non-partisan approach to Christian citizenship. He fails to adequately highlight the difficulty in managing one's earthly and heavenly nationalities. Instead, Wallis tends to speak in the language of the left, injecting the Bible as necessary in an effort to reach across the aisle. Wallis's approach also fails because of how similar it is to conservative evangelicalism's understanding of biblical citizenship. Both Wallis and his conservative evangelical counterparts tend to use the Bible as a political and rhetorical tool; they both impose particular visions of God's will on the United States' political situation. The only difference is that one vision is progressive and one is conservative. It is here that reformed evangelicalism, with Mouw as a standard bearer, sets itself apart. Reformed evangelicals distance the conception of nationalism from a partisan mindset, establishing theology as the arbiter of Christian political thought along the way. By exploring Mouw's works, reformed evangelicalism's third way for evangelicals to approach citizenship and Christian nationalism becomes evident.

\subsection{Challenging a Partisan Consensus: Richard Mouw and the Search for a Homeland}

Reformed evangelicalism is a small and a relatively unknown subgroup within the larger evangelical movement. It is defined by its approach to theology. Much like members of the larger movement, reformed evangelicals are theologically orthodox. What sets them apart is their attention to the works of reformed thinkers, prominently John Calvin (1509-1564) and Abraham Kuyper (1837-1920). A focus on these thinkers and reformed theology allows these evangelicals to engage uniquely with cultural and political issues. It also enables reformed evangelical scholars to attain a certain level of consistency and uniformity in their thinking. Whereas many evangelicals interpret the bible through a radical application of the priesthood of believers, resulting in Molly Worthen's "crisis of authority," reformed evangelicals have an established ecclesiology in which they can base their beliefs [1]. In essence, they have an authority to answer to. (In Mouw's own journey, the Canons of Dordt, the Belgic Confession, and the Heidelberg Catechism, along with the teachings of reformed scholars, serve this role [17], p. 21). Nicholas Wolterstorff (b. 1932), a philosopher and theologian, and Richard Mouw can be seen as leaders of the movement.

Mouw is a globally recognized leader of evangelicalism [18]. Indeed, he has gone out of his way to see evangelicals engage in interfaith dialogues-notably with Mormons [19,20]. Additionally, he has authored or served as an editor of over twenty books. His most recent book, Adventures

4 Luhr provides a breakdown of how evangelicals voted in 2004, indicating Wallis is correct in his claim. 
in Evangelical Civility, has received praise from evangelical leaders and non-evangelical scholars alike [21]. ${ }^{5}$ Considering his life's work, a devotion to Christian higher education, it is important to mention the multitude of addresses that he has delivered at Christian colleges around the nation. A quick YouTube search reveals many of these talks. His influence is easier to understand when one considers these following thoughts from his former colleague and friend Nicholas Wolterstorff. Wolterstorff has praised Mouw for his "concrete" theology, "conversational style", and his mastery of the "illustrative anecdote" [22]. Additionally, Wolterstorff recognizes that even Mouw's whimsical thoughts serve a deeper purpose. He speaks in a language that the laity understands and values, never discounting the pietistic roots of evangelicalism. This makes Mouw well suited to address a movement that is rightly seen as anti-intellectual. This is not to say that Mouw is not an academic and a careful thinker. He is. In that regard, he is more comparable to Harold Ockenga than either Graham or Falwell as pastors and organizers or Wallis as an activist. However, Mouw is representative of how reformed evangelicals approach the world-much like Graham, Falwell, and Wallis are representative of how their evangelical subgroups engage with the culture. Additionally, in a movement where the intellect is often lambasted, the work of academic thinkers must be, at times, compared to the impact popular leaders have. Indeed, compared to figures such as Graham, Falwell, or Wallis, Mouw's influence is very limited and is difficult to discern. Regardless, his thinking further diversifies evangelical thought, deepening and widening it in the process.

Mouw's views on Christian nationalism are often implicit throughout his writings, offering insights that soften the hardline Christian nationalism of men such as Barton or Falwell. Mouw also stands apart from progressive evangelicals such as Wallis due to his Biblicist focus. He asks for the Bible to be used for the Bible's sake. Granted, Mouw does not solely focus on the Bible's advice for nationalism, but he also does not attempt to diminish the Bible's role as the ultimate truth for his worldview, one which bridles his extra-biblical conceptions. This means that Mouw offers general, not specific, cures for the faults that he sees in evangelicals' approach to citizenship. He uses the Bible to point out the extremes of thought, offering guidance when necessary. Ultimately, however, he urges the laity to develop their own public theology without stepping over certain biblical parameters ([23], pp. 123-42). Therefore, he does not advance a sole vision for America, rather, he delights in the diversity of thought allowed for in the created order. The outcome of this thinking is an insider's corrective to evangelicals' nationalistic tendencies, overcoming efforts by progressive and conservative evangelicals to politicize the Bible in specific ways. In an attempt to connect thoughts that are spread across his many writings, five key themes will be explored due to their prominence-commonness, exile, idolatry, "many-ism," and triumphalism ([24], p. 81). Each theme sheds light on Mouw's understanding of Christian nationalism and Christian citizenship. For the purpose of this essay, Mouw's books will be primarily explored. While he has published many essays and articles, his books are written for the largest audience and are often marketed to evangelical audiences by Christian publication companies such as William B. Eerdmans. As such, they are the most likely to be read by the ordinary evangelical.

By Mouw's own admission, he sees "commonness as the theme that has been informing the main intellectual endeavors" throughout his career ([21], p. xi). As a theme, commonness' centrality to Mouw's thought makes it relevant to consider before going further. As it concerns Christian nationalism, this theme is also much harder to flesh out than the others. Essentially, commonness takes many forms in Mouw's life-a belief in common grace, a recognition of a shared likeness of God among all of humanity, and desire to seek common ground [21]. These three branches of commonness reveal a good deal about why Mouw is concerned about how Christians approach nationalism. They also serve as a good introduction to the topic.

5 The dust flap on this book reads like a who's who of Christian scholars and scholars on contemporary evangelicalism-this includes Russell Moore, Molly Worthen, and Grant Wacker. They have the highest of praise for the work Mouw has done over the years. 
The reformed notion of common grace is "a kind of non-salvific attitude of divine favor toward all human beings" ([25], p. 9). It is also a belief that Mouw adheres to very closely, inspiring his desire to seek out the good things of Christ wherever this be found. Simply put, "Grace is everywhere" ([25], p. 45). In certain reformed circles, this notion is taken quite literally. "Abraham Kuyper, for example, saw grace not only as operating broadly in human affairs; he argued that it also abounds in nature in general" ([25], p. 45). Indeed, "creation would self-destruct" without Christ's continual outpouring of grace ([25], p. 45). In essence, grace not only falls on the saved and the unsaved, it falls on creation as a whole. This means that no part of creation is exempt from the workings of grace, including nations. They all serve a divine purpose, and are sustained through the workings of Christ. (A conception of multinational chosen-ness will be explored more adequately later in this essay.) This idea of multinational chosen-ness flows well into Mouw's understanding of the image of God.

Humankind is distinguished from the rest of creation through the image that they share with the creator. Commonly, the notion of imago Dei (the image of God) is applied only to individual humans. Mouw affirms Herman Bavinck's (1854-1921) understanding of a "collective possession of the imago" ([21], p. 31). Bavinck further declares "the image of God is much too rich for it to be fully realized in a single human being" ([21], p. 32). Mouw takes this understanding and asserts,

we might think of the creator as having distributed different aspects of the divine likeness to different cultural groups, with each group receiving, as it were, a unique assignment for developing some aspect or another of the divine image. Thus, it will only be in the eschatological gathering-in of the people of the earth, when many tribes and tongues and nations will be displayed in their honor and glory in the new Jerusalem, that we will see the many-splendored imago dei in its fullness ([21], p. 32).

This too hearkens to an understanding of multinational chosen-ness and the diversity that Mouw adores in creation. Indeed, this passage indicates that national exceptionalism is only a reality if each nation is considered exceptional in its relation to Christ as lord.

Finally, in an effort to seek common ground, Mouw is affirming his belief in common grace and his communal vision of imago dei. He seeks out the image of Christ and truth, wherever they may be found, and he seeks to relate to God's likeness in the saved and unsaved alike. This has made him, in the words of George Marsden, "a builder of bridges," someone "who can find commonalities with just about anyone" [26]. Marsden's testimony illuminates Mouw's qualifications concerning the subject matter of this essay. It is in Mouw's nature to seek out that which is common among individuals and people groups rather than seeking out exceptions. This makes him a voice capable of toning down the American exceptionalism found in conservative evangelical circles by linking American Christianity to its global allies and even promoting a desire to see that which is good in its religious and international opponents. In turning to Mouw's more concrete advice concerning Christian nationalism, exile as a theme explores how Christianity supersedes earthly nationalities.

When considering exile, Mouw turns to the Puritan's view of exile, chronicling how Puritan settlers "thought of themselves as Israel wandering in the wilderness in search of a promised land" ([23], p. 47). He argues their rhetoric shifted shortly after settling in the New World. To Mouw, Puritans saw themselves as transitioning "from a wandering people to a 'Zion' people," creating a precedent for future Christian generations to do the same ([23], p. 43). From this position as the chosen people, triumphant Christian nationalism became justifiable. It is this shift in perception from exile to the chosen people Mouw seeks to combat. He believes the appropriate Christian perspective to citizenship is exile. Christians should not be at home in this world. They are exiles from their heavenly home. To cement this point, Mouw turns to 1 Peter. Here, Peter addresses "the New Testament church as a community of 'aliens and exiles'" ([23], p. 48) Mouw posits Peter was "making a theological point ... indicating how we are to understand the status of the church in the present age" ([23], p. 48). In this regard, Mouw would proudly sing along with fundamentalists that "This world is not my home, I'm just a passing through." After all, "Christians are first and foremost Christians, citizens of the theocratic commonwealth over which Jesus reigns as king" ([23], p. 48). Unlike a fundamentalist, 
Mouw would not, however, argue for cultural disengagement and the hope of an imminent eschaton. Rather, he champions the theme of exile in a different light, choosing to focus on the book of Jeremiah as a platform for viewing exile, and thereby Christian nationalism. Several of these verses are listed here as they are vital to Mouw's argument.

Thus says the LORD of hosts, the God of Israel, to all the exiles whom I have sent into exile from Jerusalem to Babylon: Build houses and live in them; plant gardens and eat their produce. Take wives and have sons and daughters; multiply there, and do not decrease. But seek the welfare of the city where I have sent you into exile, and pray to the LORD on its behalf, for in its welfare you will find your welfare (Jer. 29:4-7).

The theme of exile is obviously prominent in these verses. While Christians are exiles, they are not, in Mouw's opinion, to be culturally disengaged. They are also not forbidden from loving their country. In order to discern how one can love their country, yet avoid being a Christian nationalist, Mouw points to a word hidden in the translation. He explains the word for "welfare" in the Hebrew text is shalom. Mouw chronicles the "richer meaning" of the word, a meaning that goes beyond the common interpretation of peace and welfare ([24], p. 69). Shalom is rightly interpreted as justice and flourishing. As Mouw understands it, Jeremiah is telling the exiled Israelites "neither indifference nor hostility is a proper way of treating our pagan neighbors [or our fellow citizens]. We must seek their shalom" ([24], p. 70). By framing the debate over commitment to one's earthly home in the context of exile, Mouw does not demand Christians cease to love their earthly home, nor does he ask them to stop seeking its success. Rather, he modifies the aim. Christians are called to seek their nation's success without forgetting they are exiles, merely passing through to their true homeland, the one that demands their deepest affections.

Mouw's understanding of exile and its relation to Christian citizenship satisfies the intense Biblicism evidenced in the evangelical movement ([27], pp. 13-14). ${ }^{6}$ However, unlike conservative and progressive evangelicals, Mouw does seem to use the Bible for its own sake [28]. ${ }^{7}$ He does not advance an explicit political agenda through the theme of exile. Nor does he outline exactly how Christian citizens should behave in any given nation. Rather, he quite simply states that Christians should seek the welfare of their nation without losing sight of their true home. The ambiguity of this theme should be striking considering how often evangelicals politicize the Bible to support policy measures. Mouw also chooses not to mention any modern nation by name while discussing exile. In doing so, he opens the door for Christians to seek the welfare of any earthly nation in which they reside. He further downplays the importance of worldly citizenship while emphasizing the national identity of the body of believers. In sum, Mouw declares Christians' only true nation is the kingdom of God. They must behave accordingly in their temporary homes, but they must never assume their earthly nations can represent the Kingdom of God. To quote Mouw, "Absolute loyalty is something that only God deserves from us [Christians]" ([29], p. 117).

This informs Mouw's attack on idolatrous Christian nationalism. In one of his more critical thoughts, Mouw recalls the post September 11 reaction of evangelicals. He found it similar to the "super-patriotic" attitude of evangelicals during the Vietnam War ([29], p. 116). He especially remembered the chants of "My country, right or wrong" evangelicals employed during that war ([29],

6 It is worth noting that, while he does believe in Sola Scriptura, Mouw would not go so far as to say that the Bible alone holds all truth. Rather, it holds ultimate truth. He believes truth can be found through scientific exploration as just one example. He details these beliefs in his book Called to the Life of the Mind.

7 This portion of the paper borrows from Mark Noll's In the Beginning was the Word: The Bible in American Public Life. Noll expertly illustrates how the Bible has oft been used by American Christians, particularly evangelicals in the colonial era, and I would contend beyond the colonial period, to advance agendas that are not biblical. Noll indicates how the Bible has been used to advance and contest Christendom, how the Bible has been thinned or absorbed into the sciences and political thought, and how it has been, at times, a Bible for the Bible's sake. A brief summation of this argument can be found on page 329 of In the Beginning was the Word. 
p. 116). In both the Vietnam War and the post-9/11 climate, evangelicals had an unquestioning love of country. While Mouw affirms there is a place for proper patriotism, he does state "That kind of patriotism struck me as bordering on idolatry" ([29], p. 117).

Furthermore, in an essay exploring the role of national icons in church settings, he declares "Our [Christians'] worship services are gatherings in the divine throne-room, where we acknowledge that our true loyalties belong to God alone. Nothing in our liturgical content or setting should detract from this expression of fidelity" [30]. To be clear, Mouw is not expressing a desire to ban flags and the like from church services unless they are a distraction to the congregation. Apart from national symbols, Mouw also addresses the way Christians worship, particularly through song. He cites the "dangerous teachings" many patriotic songs convey [30]. For instance, "Themes that in the book of Revelation are used to describe the Holy City are here applied to the United States: 'alabaster cities,' 'undimmed by human tears,' the 'shining sea.' As if the United States will become the promised New Jerusalem! [30]". This attention to the content churchgoers often accept denotes his fear of the "very real threat" idolatry poses [30]. Mouw reaffirms the "multinational character of the body of Jesus Christ" [30]. He then shifts towards his views on healthy patriotism. Hearkening back to his understanding of exile. Mouw contends

Christians need to work hard at keeping patriotic feelings within proper bounds. There is nothing wrong with loving my country ... However, this does not put my country beyond criticism. To honor our nation in a godly manner is to want it to contribute to the cause of Christ's kingdom. To love our country with a Christian love is to want our nation to do justice and love mercy and walk in humility before the face of the Lord. [30]

His own understanding of idolatry is further informed by an exploration of his Kuyperian sensibilities. Mouw borrows Kuyper's conception of sphere sovereignty when discussing idolatry. Boiled down, sphere sovereignty is a theological idea wherein each area of life-such as family, government, church, art, and the economy to name just a few-are relegated to separate spheres. Each sphere ultimately answers to God. However, apart from the government on a limited basis, spheres cannot infringe on other spheres ([31], pp. 33-34). ${ }^{8}$ The blurring of boundaries is, in itself, a form of idolatry because, according to Kuyper, these spheres were mandated by God. Any attempt to infringe on these boundaries or to have one sphere subsume another sphere would be a deeply idolatrous action. Mouw offers a brief corrective to this Kuyperian conception without disregarding the notion of sphere sovereignty. He contends spheres can step in to supplement weaker spheres if necessary. For example, Mouw believes the church must step in to bolster the family sphere if it is not strong enough to thrive on its own. The church cannot become the family though. "While the two modes [spheres] may be combined, they must not be confused" ([32], p. 51). Therefore, while Mouw contests certain aspects of sphere sovereignty, he does believe each sphere has its own special role, and he does not object to Kuyper's conception of idolatry as the blurring of these boundaries.

Mouw's own view of idolatry is, therefore, rightly seen as an extension of Kuyper's. Idols are often made from "something that is a good part of Creation;" they come about from the worship or improper understanding of the relation between created and creator ([31], p. 21). Notably for evangelicals, Mouw believes "Political parties and movements are worthy of our respect when they are kept in their place-in their proper sphere of life" ([31], p. 21). It would not be improper, I believe, to claim that Mouw would express a similar belief for nations. If a nation is conceived of as more important than God intended and is heavily relied on to maintain a certain lifestyle, it too can be seen as an idol. Mouw once again emphasizes the created should worship and rely on the creator alone. The created should not elevate the importance of the political or the national in such a way that

8 The government is only allowed to interact across spheres out of necessity. It maintains boundaries, protects the weak from the strong in spheres, and allows spheres to run efficiently. Quite simply, all the spheres use roads. The government is in charge of infrastructure; therefore, the government interacts with all spheres. 
God's role as king over all is diminished even slightly. Such an action would not only be dangerously idolatrous, it would also elevate one sphere above others in a way that downplays God's creational diversity. Here, Mouw's notion of many-ism comes to the fore.

Many-ism is more than a simple recognition and appreciation of diversity. It is fueled by a profound love of the created order. In this regard, it is connected to the idea of sphere sovereignty. Many-ism began with the cultural mandate. This mandate originated, according to Mouw, in the Garden of Eden ([33], p. 126). Intended by God to fill the earth, humanity was expected to do more than multiply. Men and women were also designed to be a lesser, co-creator. One of the more important tasks given to the co-creator was the development of cultures and, thereby, cultural diversity. Mouw contends that the God of the Bible strongly dislikes "deadly uniformity" ([24], p. 81). ${ }^{9}$ He particularly cites the words of Genesis 1:20 — “Let the waters bring forth swarms of living creatures" ([24], p. 82). The God that Mouw sees in the bible delights in these swarms. It is an almost childlike celebration of diversity. Mouw does not argue that God could not have created a uniform universe. Instead, he believes that God loves diversity. In a way, Mouw implies that "deadly uniformity" would simply not be as enjoyable to God ([24], p. 81).

There are several lessons that many-ism can teach Christian nationalists. In particular, it stands in stark contrast to the national exceptionalism that most evangelicals take. A short look at Mouw's interpretation of Isaiah 60 lends credence to this claim [34]. For those unfamiliar with this chapter of Isaiah, it is a prophetic passage focused on the restorative work of God over all of creation at the end of days. Notably, it is the moment when the nations of the earth, along with elements of nature, are called before the throne of God. A brief passage from Isaiah informs this point- “'Your [the kingdom of God's] gates shall be open continually; day and night they shall not be shut; that men may bring to you the wealth of the nations, with their kings led in procession" (Isaiah 60:11). God calls the nations to him so that he may restore them. The plurality displayed by "nations" is telling. Isaiah does not single out a nation or a king. Obviously, the United States was not a nation during biblical times; therefore, it is not listed in Isaiah 60. Yet, many nations are listed in the chapter, and their cultural achievements are called before the throne of God to be restored and called good. In Mouw's own words, the act of assembling "kings together, then, was in an important sense to assemble their national cultures together" ([34], p. 50). Interestingly, and this is a pattern that can be found through all of his books, Mouw does not inject the United States into the biblical narrative. This may seem like a minor point, yet one does not need to dig deeply into evangelical history to find frequent attempts by evangelicals to place the United States biblically [4]. Rather, Mouw seeks to affirm something that can be seen as deeply biblical. All of creation is chosen and ordered by God. Therefore, each and every nation is chosen by God to some degree ([34], p. 57). They are all providentially guided, and they will all find themselves called to account before the throne of God to be restored to their created goodness.

To be sure, this interpretation of Isaiah 60 is informed heavily by Mouw's Calvinism and Kuyperiansim. His Calvinist sensibilities are satisfied by the sovereignty of God displayed in Isaiah 60, and his Kuyperian sensibilities are satisfied by the restoration of the created spheres to their proper order-God once more is recognized as ruler over them all. However, Mouw is also evincing a deeply evangelical reading of this passage. He takes the text, quite simply, at its word. God calls the nations and chooses to restore them all. This connotes a rejection of the exceptionalism or chosen-ness of one nation. They may be called for different purposes, but they are all chosen. For the nationalistic evangelical, this quells a recognition of America as exceptional. It places God firmly as king and ruler over all, in such a way that one nation does not come to the fore. To put it in Kuyperian terms, "There is not a square inch in the whole domain of our human existence [nations included] over which Christ,

9 Mouw borrows this phrase from South African politician Nic Diedrich. While Diedrich used these words to defend apartheid's forced segregation. Mouw uses these words for a different purpose. He intends, in the original context, to illustrate how God's distaste for uniformity breathes life into a kind of godly, cultural pluralism. 
who is sovereign over all, does not cry 'Mine!'” ([31], p. 4). ${ }^{10}$ Despite the triumphant nature of this claim, Mouw urges his readers to balance this perspective, softening it in the process. It is here where Mouw's opinions on triumphalism become relevant.

The western world has, in Mouw's opinion, long worshipped a triumphant Christ. Japanese theologians have been particularly critical of this view. Mouw cites Kosuka Koyama to support this claim. "A strong Western civilization and the "weak" Christ cannot be reconciled harmoniously. Christ must become "strong." A strong United States and a strong Christ!" ([35], p. 3). Koyama contrasts this Western viewpoint with a depiction of Christ found in the "image of the same broken Christ who comes to us every time we approach the Lord's Supper" ([35], p. 3). Mouw does not challenge the triumphant image of Christ. He, in fact, affirms it in several ways. First, Christ is victorious over sin. He then extends that victory to his followers. Finally, Christians should be proud of this victory ([24], pp. 163-64). This is not, however, an excuse for Christians to claim "the spoils of Christ's victory" ([24], p. 165). In an effort to illustrate his point, Mouw offers Mother Teresa as an example of how a victorious Christ can be balanced by a suffering Christ.

The life of Mother Teresa cannot be fully understood without understanding her love for the broken Christ. The most prominent example, in Mouw's view, was her advice to nuns that aided her in Calcutta. She encouraged them to find Christ "in his dreadful disguise, among the poorest of the poor" ([31], p. 135). For Mouw, this is not a rejection of a triumphant Christ. Even on Calvary, at his most vulnerable, Christ stood triumphant. A recognition of the suffering Christ does, however, focus on an aspect of Jesus that is often overlooked, the one who suffered, and encouraged his followers to suffer with him.

Mouw argues that "the lack of earthly suffering in the lives of white American theologians" could have led to this dominant vision of a triumphant Christ ([35], p. 62). He contrasts this Caucasian understanding of Christ with that of slaves in the Western Hemisphere. Negro spirituals convey this point excellently. As just one example, "Nobody knows de trouble I see Lord, nobody knows like Jesus" ([35], p. 65). The suffering develops a Christology focused on a Christ who suffers rather than a triumphant Christ. Mouw contends that both views are theologically correct. This leads back to his main point. Christ is victorious even in his suffering, but he alone lays claim to that victory. The Christian cannot seize that right. What the Christian is left with, according to Mouw, is a Christ who still claims "Mine" over all of creation while still evincing an image of the Christ "whose 'footprints are splattered with blood'" ([31], pp. 132-33).

Mouw's Christological understanding of Christ is different than the savior conservative and progressive evangelicals serve. It highlights a Christ who does not serve political interests and one that does not necessarily support national triumphs. Instead, it is a Christ who stands above his creation with his arms outstretched, as they were on the cross, awaiting the day when he can once more joyfully say "'Mine!' over the creation that he has made new" ([31], p. 134).

\section{Conclusions}

The post-World War II re-awakening of evangelicalism deeply impacted the history of the United States. It led to a bolstering of conservatism in the nation advanced by a movement that predominantly believed God chose the United States for a great purpose. This belief manifested itself in a Christian nationalism wherein conservative evangelicals argued the nation was exceptional because it was chosen by God. More importantly though, this sense of chosen-ness, combined with an entrenched sense of Biblicism, gave right-wing evangelicals the perception that political compromise was dangerous and a lack of patriotism evinced a lack of faith in God's will. The result of this belief was an evangelicalism that often unquestioningly supported the national direction, particularly when the Republican Party sat in the halls of power.

10 Mouw is quoting Abraham Kuyper. 
Focusing on this singular perception of evangelicalism ignores the reality of a movement better defined in terms of diversity. Competing attempts to interpret the Bible and determine its impact on the world left evangelicals with a "crisis of authority" ([1], p. 265). While conservative evangelicals held a lion's share of the movement's power, evangelical subgroups cultivated differing opinions. Within this context, certain figures were seen as authoritative. Conservative evangelicals see figures such as Graham and Falwell as anointed and progressives see Wallis in a similar light. However, to see any of these figures as the only ones worth listening to and studying overlooks important lines of thought.

Mouw is representative of one such alternate viewpoint-reformed evangelicalism. In his effort to defend the Bible's core message, he evinces a desire to appreciate the general will of God. He often shies away from particulars. While this can be contrived as a weakness in his line of thought, it does differentiate him from most evangelicals regardless of their political affiliation, highlighting his ability to rise above the "schisming and squabbling" common within the movement ([1], p. 7). Through his desire to build a Christian foundation to citizenship, rather than decorate the house as it were, Mouw also stands apart from conservative evangelicals such as David Barton. Barton's focus on particulars leaves little to the imagination. His only conception of citizenship for the evangelical is one of loyalty. This is because of America's supposedly chosen nature. To oppose what is chosen by God cannot be allowed in Barton's thinking. To this, Mouw would likely say God dislikes "deadly uniformity" ([24], p. 81).

Furthermore, Mouw delights in the diversity of creation, even if it is currently depraved, while never losing hope in its renewal. Behind this hope is an unquestioning belief that Jesus is Lord over all. All of creation is his; it has all been chosen for his purpose. This means God is not merely lord over the United States, nor has he chosen one nation to serve his purposes. He has, instead, chosen all nations in his eternal plan. Through this view of Christ and creation, Mouw restores the image of a Christ who deeply empathizes with and defends those who are suffering. Christ, though triumphant, does not bow to or serve the powers of this earth. To put it quite simply, Mouw's views on the God of the Bible and of Christians' earthly responsibilities contextualizes evangelicals' earthly role by reminding them who is triumphant, and they are "just a-passin' through." He urges their deepest affections to reflect that reality.

Conflicts of Interest: The author declares no conflict of interest.

\section{References}

1. Worthen, Molly. Apostles of Reason: The Crisis of Authority in American Evangelicalism. New York: Oxford University Press, 2014.

2. Green, Stephen K. Inventing a Christian America: The Myth of the Religious Founding. New York: Oxford University Press, 2015.

3. Stephens, Randall J., and Karl W. Giberson. The Anointed: Evangelical Truth in a Secular Age. Cambridge: Belknap Press, 2011.

4. Sutton, Matthew. American Apocalypse: A History of Modern Evangelicalism. Cambridge: Belknap Press, 2014.

5. Hart, Darryl G. That Old Time Religion in Modern America: Evangelical Protestantism in the Twentieth Century. Chicago: Ivan R. Dee Publishing, 2002.

6. Preston, Andrew. Sword of the Spirit, Shield of Faith: Religion in American War and Diplomacy. New York: Anchor Books, 2012.

7. Kruse, Kevin. One Nation Under God: How Corporate America Invented Christian America. New York: Basic Books, 2015.

8. Stephens, Randall J., and Karl W. Giberson. The Anointed: Evangelical Truth in a Secular Age. Cambridge: Belknap Press, 2011.

9. Carpenter, Joel. Revive Us Again: The Reawakening of American Fundamentalism. New York: Oxford University Press, 1997.

10. Wacker, Grant. America's Pastor: Billy Graham and the Shaping of a Nation. Cambridge: Belknap Press, 2014. 
11. Self, Robert. All in the Family: The Realignment of American Democracy since the 1960s. New York: Hill and Wang, 2012.

12. Hankins, Barry. Francis Schaeffer and the Shaping of Evangelical America. Grand Rapids: William B. Eerdmans Publishing Company, 2008.

13. Swartz, David. Moral Minority: The Evangelical Left in an Age of Conservatism. Philadelphia: University of Pennsylvania Press, 2012.

14. Gasaway, Brantley. Progressive Evangelicals and the Pursuit of Social Justice. Chapel Hill: The University of North Carolina Press, 2014.

15. Wallis, Jim. God's Politics: Why the Right Gets It Wrong and the Left Doesn't Get It. New York: Harper One, 2005.

16. Luhr, Eileen. Witnessing Suburbia: Conservatives and Christian Youth Culture. Berkeley: University of California Press, 2009.

17. Mouw, Richard. Calvinism in the Las Vegas Airport: Making Connections in Today's World. Grand Rapids: Zondervan Press, 2004.

18. Fuller Theological Seminary. "Friends Pay Tribute to Dr. Mouw's Legacy." Available online: http://cms.fuller. edu/RJMouw/root/Home/Friends_Pay_Tribute_to_Dr_Mouw_s_Legacy/ (accessed on 21 December 2016).

19. Mouw, Richard. Talking with Mormons: An Invitation to Evangelicals. Grand Rapids: William B. Eerdmans Publishing Company, 2012.

20. Mouw, Richard, and Robert Millet, eds. Talking Doctrine: Mormons and Evangelicals in Conversation. Downers Grove: Intervarsity Press, 2015.

21. Mouw, Richard. Adventures in Evangelical Civility: A Lifelong Quest for Common Ground. Grand Rapids: Brazos Press, 2016.

22. Wolterstorff, Nicholas. "Richard Mouw: Reflections on His Writing." Available online: https:/ perspectivesjournal. org/blog/2013/07/01/richard-mouw-reflections-on-his-writing/ (accessed on 6 December 2016).

23. Mouw, Richard. Called to Holy Worldliness. Philadelphia: Fortress Press, 1980.

24. Mouw, Richard. Uncommon Decency: Christian Civility in an Uncivil World. Downers Grove: IVP Press, 2010.

25. Mouw, Richard. He Shines in All That's Fair: Culture and Common Grace. Grand Rapids: William B. Eerdmans Publishing Company, 2001.

26. Marsden, George. "Rich Mouw: A Fundamentalist with a Sense of Humor." Available online: https:// perspectivesjournal.org/blog/2013/07/01/rich-mouw-a-fundamentalist-with-a-sense-of-humor/ (accessed on 6 December 2016).

27. Mouw, Richard. Called to the Life of the Mind: Some Advice for Evangelical Scholars. Grand Rapids: William B. Eerdmans Publishing Company, 2014.

28. Noll, Mark. In the Beginning Was the Word: The Bible in American Public Life, 1492-1793. New York: Oxford University Press, 2016.

29. Mouw, Richard. Praying at Burger King. Grand Rapids: William B. Eerdmans Publishing Company, 2007.

30. Mouw, Richard. "The Danger of Alien Loyalties: Civic Symbols Present a Real Challenge to the Faithfulness of the Church's Worship." Available online: http:/ /www.reformedworship.org/article/march-1990/dangeralien-loyalties-civic-symbols-present-real-challenge-faithfulness-churchs- (accessed on 6 December 2016).

31. Mouw, Richard. Abraham Kuyper: A Short and Personal Introduction. Grand Rapids: William B. Eerdmans Publishing Company, 2011.

32. Mouw, Richard. The Challenges of Cultural Discipleship: Essays in the Line of Abraham Kuyper. Grand Rapids: William B. Eerdmans Publishing Company, 2012.

33. Mouw, Richard, and Sander Griffoen. Pluralisms and Horizons. Grand Rapids: William B. Eerdmans Publishing Company, 1993.

34. Mouw, Richard. When the Kings Come Marching In. Grand Rapids: William B. Eerdmans Press, 2002.

35. Mouw, Richard, and Douglas A. Sweeney. The Suffering and Victorious Christ: Toward a More Compassionate Christology. Grand Rapids: Baker Publishing Group, 2013.

(C) 2016 by the author; licensee MDPI, Basel, Switzerland. This article is an open access article distributed under the terms and conditions of the Creative Commons Attribution (CC-BY) license (http:/ / creativecommons.org/licenses/by/4.0/). 